\title{
Comparison and Gradation in Indo- European: Introduction and Overview
}

Keydana, Götz ; Hock, Wolfgang ; Widmer, Paul

DOI: https://doi.org/10.1515/9783110641325-001

Posted at the Zurich Open Repository and Archive, University of Zurich

ZORA URL: https://doi.org/10.5167/uzh-203515

Book Section

Published Version

Originally published at:

Keydana, Götz; Hock, Wolfgang; Widmer, Paul (2021). Comparison and Gradation in Indo- European: Introduction and Overview. In: Keydana, Götz; Hock, Wolfgang; Widmer, Paul. Comparison and Gradation in Indo-European. Berlin: de Gruyter, 1-34.

DOI: https://doi.org/10.1515/9783110641325-001 


\section{Götz Keydana, Wolfgang Hock and Paul Widmer}

\section{Comparison and Gradation in Indo- European: Introduction and Overview}

\section{The Basics}

"Fundamental to cognitive processing and the structuring of experience is our ability to compare events and register any contrast or discrepancy between them" (Langacker 1987: 101). It is hardly a surprise then that all known human languages have ways to express comparisons. What makes comparison such a rewarding topic for typological studies is the fact that it can be expressed by various means ranging from pragmatics to fully grammaticalized constructions.

The most frequent and possibly most fundamental type of comparison (see Jäger 2018: 433 with fns. 424, 425, 434) is one in which the listener/reader is invited to conceptualize one entity in terms of another entity. Typically, the two entities compared belong to fundamentally different ontological categories:

\section{(1) John is like a lion.}

Comparisons of this type are holistic: While the most salient properties relevant for the comparison may be made explicit or may be inferred from the context, they always evoke the whole concept of the comparandum. Thus, a discourse like the following is felicitous:

(2) A: John won the heavyweight championships.

B: Yes, he is like a lion.

A: He hasn't got a mane, though.

Comparative constructions like the one in (1) are called similatives. They will be discussed in greater detail in section 2.

Other types of comparison aim at specific properties pertaining to the compared individuals. They involve what Langacker (1987: 104) calls 'selection' and some type of gradation relative to the selected property. Gradation is the notion of explicitly assigning an entity a position relative to some other contextually relevant value(s) on a predicative scale. Gradation is thus always extent-based (Seuren 1973, von Stechow 1984, Kennedy 2001, Beck 2011). For example, (3) explicitly assigns Peter a value on the scale of body size that is closer to 'tall' than to 'small'. 
(3) Peter is rather tall.

According to Sapir "[e]very quantifiable, whether existent (say house) or occurrent (say run) or quality of existent (say red) or quality of occurrent (say gracefully), is intrinsically gradable” (1944: 94). Thus house is gradable with respect to size, height, number of rooms etc., running with respect to speed, excitement of runner, length of time, red with respect to intensity or degree of conformity to some accepted standard of redness, and gracefully with respect to "activities which may be arranged in a graded series on the score of gracefulness" (ibid.). This implies that gradation is possible with various word classes such as nouns, verbs, adjectives, and adverbs. However, the prototypical comparanda are entities. It is thus not surprising that typologists have stressed the fact that gradation prototypically applies to adjectives (Jensen 1934: 109, Cuzzolin 2011: 563, Dixon 2012: 343) though it is actually attested in IE languages with all the word classes mentioned above.

Not only gradation, but gradability itself necessarily implies comparison. Consider:

\section{(4) David is smart.}

In (4) (cf. Heine 1997: 109), for instance, a speaker seems to intend nothing apart from ascribing a property to David. This is similar to a sentence like (5), where the adjective denotes a non-gradable property:

\section{(5) David is dead.}

However, a relative adjective like smart necessarily implies a comparative class relative to which the property denoted is evaluated. This class differs depending on the primum comparationis: Classifying a human as smart implies a different comparative class and thus a different value on a scale of smartness than doing the same with a cat as in (6):

(6) This cat is smart.

Values can be defined as equivalence classes (von Stechow 1984).

Non-gradable properties like dead, on the other hand, can be evaluated independently of comparison classes although they can always be coerced into gradient readings:

(7) The American Dream is even more dead than you thought. (nymag, 10/07/2016) 
As a consequence of gradability, it is not uncommon to consider ungraded expressions like smart in (4) as a neutral pattern of grading, dubbed the 'positive' (Cuzzolin 2011: 552), or "implicitly gradable but ungraded" (Sapir 1944: 94). Since the positive fails to mark grading explicitly, it will be excluded from our survey unless it is used in comparative constructions. However, a caveat is in order: It is easy to come up with contexts in which an ungraded adjective like smart in (4) explicitly assigns David a value different from another possible value. In English this may happen when presuppositions and attitudes are being evaluated and compared (often, such a reading is marked by a dedicated intonation pattern):

(8) Wow, David is smart! I wasn't aware of that! [= David is exceedingly smart]

(9) A: I have the impression that David is stupid.

B: You are wrong, David is smart! [= David is smarter than you think].

Acknowledging that the language-specific expression of gradation as defined above is multi-faceted and may interact with pragmatic factors in quite intricate ways, we take a hands-on approach: We focus on the explicit morphosyntactic and -phonological realization of gradation that sets gradation apart from expressions that are neutral in this respect. This approach is reasonable since in the kind of extinct corpus languages we are concerned with here it is often impossible to detect the subtleties of pragmatic inference in the first place. But it goes without saying that if in a given language some type of grading is systematically encoded exactly like the respective ungraded category, this type of comparison is documented.

With extent comparisons, two basic types can be distinguished (see already Small 1929: 12-13), namely comparisons of equality and comparisons of inequality. Concerning the latter, we can differentiate between comparisons of majority (or superior comparatives) and comparisons of minority (or inferior comparatives). As Cuzzolin (2011: 552) observes, the existence of formal means expressing the latter implies the existence of formal means expressing the former.

The following fundamental relations are possible in extent comparisons: Comparison involves two entities $x$ and $y$ (or sets of entities $X$ and $Y$, the comparison class). The properties $P$ and $Q$ are attributed to $x$ and $y$ (or the members of $X$ and $Y$ ), respectively, and the values of $P(x)$ and $Q(y)$ are compared relative to a scale. The entities $x$ and $y$ may constitute different referents $(x \neq y)$ or they may be coreferent $(x=y)$. The properties may differ $(P \neq Q)$ or not $(P=Q)$. If they differ, they are conceptualized as 
commensurable in a given context. ${ }^{1}$ Throughout this book, $x$ is called the comparee (CPREE), $y$ the standard (STAND), and the properties compared the parameter(s) (PAR). ${ }^{2}$

Comparisons of inequality are statements about differing values attributed to one or more entities on a gradable scale with respect to one or more gradable properties. An example of this, the most frequent type of extent comparison, is (10):

\section{(10) Peter is smarter than David.}

In (11) two properties pertaining to one entity are involved:

(11) John is more cautious than effective. (adapted from Cuzzolin 2011: 566)

The existence of this type necessarily entails that of the prototypical one. We are not aware of any language where the types with one entity and/or more than one property differ structurally from the prototype. Thus, pace Hahnemann (1999: 2), they will not be addressed separately in the following. However, since comparisons involving only one entity and/or more than one property tend to be rare, we intend to illustrate them if pertinent data are available. In this we follow typological studies in gradation like Ultan (1972: 119) and Dixon (2008: 809, 2012: 367). Beck et al. (2004) point out that comparatives with more than one property are excluded in Japanese. But since the ungrammaticality of a construction cannot be deduced from its absence from a corpus, such conclusions are unattainable for the languages under consideration in this volume. ${ }^{3}$

Comparisons of equality are statements about values that are considered to be near-identical or identical (presupposing a contextually given granularity). In (12), the values of two dimensions of a three-dimensional space are said to be identical on a scale commonly used to measure three-dimensional extensions.

(12) The room is as high as it is wide.

Comparison of equality, though generally recognized as a type of comparison, is cross-linguistically underexplored (Ultan 1972: 134, Haspelmath \& Buchholz 1998: 277, Treis \& Vanhove 2017: 1).

1 Cuzzolin (2011: 566) argues that in such cases, e. g. (10) below, "there is no real comparison" and that "the qualities involved are not put on any scale at all, since they are intrinsically of different value." We reject this argument: In extent comparisons, the compared properties are always conceptualized as comparable relative to some scale, even if this implies coercion.

2 Compare below section 3 on the basic constituents of comparative constructions.

3 The restrictions of non-informant corpus languages are also the reason why we cannot address further issues discussed in Beck et al. (2009). 
In equality and inequality constructions alike, the standard may either be specific, i. e. referring to individual discourse referents, or generic, i. e. referring to classes. Cf. (13) and (14):

(13) Peter is as tall as a basketball player.

(14) Peter is taller than a basketball player.

In the following, we give a detailed notional overview of grading constructions (section 2), followed by a detailed classification of construction types realizing these notional patterns and an introduction to the terminology used in this study (section 3). In the last section we give an overview of the morphosyntax, the morphonology, and the syntactic patterns of the basic elements of grading constructions with special attention to the expression of the graded property (section 4).

\section{Notional overview}

The notional overview given in this chapter is neither hierarchically organized nor exhaustive. It provides the main types of grading and comparison as defined above. The main classification centers around the nature of the comparison between the values on a scale related to one another by the grading construction, the one exception being the similative. Each type is illustrated by examples. For more data and further subclassification, see section 3.

\section{Similative}

An entity of one category is conceptualized in terms of another category. ${ }^{4}$ As mentioned above, similatives are holistic. Haspelmath \& Buchholz (1998: 278, 313) and Vanhove $(2017: 196,199)$ call them comparisons of manner. ${ }^{5}$ Prototypically, the standard is of a different category than the comparee. Thus, figurative similatives are frequent:

(15) My father is like a mountain.

Conceptualizing the comparee in terms of the standard presupposes that the standard be already part of the discourse universe or the common ground. This fact was claimed

4 We thank Agnes Jäger and Nina de Kreij for their invaluable input on similatives.

5 Cf. the more cautious formulation in Jäger (2018: 13): “... prima facie keine Gradsemantik..., sondern etwa Arten und Weisen.” Jäger (ibid.) opts for the term "Nicht-Grad-Äquativ” and proposes a feature based semantics "[- Ungleichheit, - Grad]" (2018: 433). Others explain similarity as a concept denoting “similar features” (Jenny 2017: 293) or “partial identity” (Haspelmath 2017: 13). 
to be a general feature of comparisons by Small (1929: 12). However, while with extent comparisons contexts are conceivable where the standard is not already familiar (see below ex. 27), this is impossible in the case of similatives.

Parameters guiding the conceptualization may be added:

(16) My father is tall like a mountain.

(17) Michael Jackson moves like James Brown.

Degree readings, if they emerge, are epiphenomena of the use of gradable concepts as parameters (e.g. tall in ex. 16). They are not intrinsic to the similative construction. ${ }^{6}$ Rather, parameters profile aspects of a holistic concept without ousting others. Thus, the following utterance would be slightly odd since the similative evokes the whole gestalt of a mountain, not only its height:

(18) \#My father is tall like a mountain. He is awfully skinny.

A noteworthy feature of the similative which sets it apart from the equative is the fact that it always entails the positive of the parameter. ${ }^{7}$

(19) \#Peter is tall like George. Actually, he is rather small.

This entailment is a crucial difference between similatives and equatives and can be used as a heuristics distinguishing the two.

Special cases of the similative are sentences like (20), spoken with a pause before the standard marker like:

\section{(20) Peter is tall, like George.}

Sentences like (20) state that in a given situation two propositions are true, Peter is tall and George is tall. In other words, this type compares propositions. This type of similative does not imply that the standard is already given.

Another special case of the similative is the hypothetical comparison or simulative (Treis 2018: iii):

(21) Michael Jackson moves as if he were James Brown.

\footnotetext{
6 We assume that this is what Jäger (2018: 13) has in mind when stating that "Nicht-Grad-Äquative besitzen damit [...] keine ausschließlich gradbasierte Semantik, wobei unter Umständen die verglichene Art und Weise auch Grade einer Eigenschaft umfassen kann, grundsätzlich aber eine ganze Reihe von ggf. auch nicht-graduierbaren Eigenschaften eine Rolle spielt.”

7 Entailment of the positive is the reason Thurmair (2001: 149) calls similatives 'polar comparisons'. We find this use of the word polar slightly misleading.
} 
This type explicitly highlights the counterfactual nature of the comparison.

With similatives, the following basic relations may hold: $x \neq y, x=y$ (if the profiled $P \neq Q$ ), profiled $P=Q$ and profiled $P \neq Q$. As with equatives, some languages (such as Dutch) distinguish specific and generic similatives. In the languages discussed in this volume, we found no evidence for this distinction.

\section{Equative}

The score on a scale of the property (resp. properties) attributed to the compared entities or sets of entities is identical or near-identical within a contextually given granularity. Ex. (22) states that on a scale of body size John's score is identical to the score of George.

(22) John is as tall as George.

The following basic relations may hold: $x \neq y, x=y$ (if $P \neq Q$ ), $P=Q$ and $P \neq Q$. The granularity may be made explicit as in (23):

(23) John is roughly/exactly as tall as a basketball player.

Equatives do not entail the positive of the parameter. Thus, a sentence like (24) is felicitous:

(24) John is as tall as George, but actually he is rather small.

In (23), the standard, to which John is compared, has generic reference, while in (24) the reference is specific. Languages like Lizu, Tibeto-Burman, use different constructions depending on the reference. The languages in our sample do not formally distinguish the two types of reference, although there are tendencies to prefer certain constructions over others in generic contexts in Latin (see Ittzés, this volume). A difference between predicative and adjunct uses of equatives is attested in Greek (de Kreij, this volume).

Equative semantics are also attested with comparatives. This is the case of the correlative conditional or correlative diptych in the sense of Cuzzolin (2011: 639):

(25) The more, the merrier!

Similarly, comparatives with standards conceptualized as the endpoint of a scale are often classified as equatives. Cf. ex. (26):

(26) The dentist's teeth are whiter than snow. 
Hyperboles like this are widely attested in our sample. Their exact semantics is contested; see most recently Ittzés (fthc.) as well as the contributions of de Kreij and Ittzés to this volume.

As with other extent comparisons, the standard is typically part of the discourse universe. Other than with similatives, however, givenness is not a necessary condition on standards:

(27) A: Peter is smaller than his parents.

$\mathrm{B}:$ At least he is taller than his brother!

This discourse is felicitous even in contexts where the fact that Peter has a brother is new to the hearer.

Depending on the language, the formal means of expressing equatives and similatives may differ, as in e.g. Albanian, Classical Armenian, and the Insular Celtic languages (the latter with designated morphemes to mark equatives). If they do not differ, as in the other languages in our sample, the exact demarcation between both types of comparison is sometimes impossible to draw. In such cases, entailment of the positive is a crucial criterion. But this, too, has its limits: One comes from the fact that we are dealing with non-informant languages. Testing for entailment is therefore next to impossible. The other is more fundamental: While entailment is a necessary property of similatives, the opposite, namely that equatives never entail the positive, is not true. Compare the following examples:

(28) \#John's teeth are white like milk. Actually, they are yellow.

(29) \#John's teeth are as white as milk. Actually, they are yellow.

(28) is a similative, and the entailment relation is as expected. The utterance is therefore odd. However, the same is true of (29), an equative. Equatives entail the positive if it is known from the context or from world knowledge that the positive is true for the standard. This is clearly the case of milk in (29), but not in the case of (24) above.

\section{Comparative}

The score of the property (resp. properties) attributed to the comparee is different from that of the same or a commensurable property attributed to the standard, as exemplified by (30)-(32):

(30) John is smarter than George.

(31) John is less smart than George.

(32) John is dumber than George. 
The score of the property attributed to the comparee may be higher on the scale or lower on the scale. Thus, we may distinguish a comparative of superiority/majority and a comparative of inferiority/minority. To our knowledge, the latter is never expressed by a construction which, apart from the morphemes used, differs from that of the former. Note, however, that the parameter marker in inferiority constructions is never a bound morpheme. Inferiority may also be expressed lexically by use of a polar adjective, as in (32).

The difference on the scale can be made explicit as in (33):

John is taller than George by $5 \mathrm{~cm}$.

This type was labeled 'differential comparative’ by Beck (2011: 1383 et passim).

As noted above, with comparatives it is possible to compare a comparee and a standard relative to two parameters which are conceptualized as commensurable. See (34) as well as (11) above:

(34) John is taller than George is broad.

This type is called subcomparative by Bresnan (1973) and Beck (2011: 1342). In languages like Japanese, subcomparatives are blocked (Beck et al. 2004: 290). We are not aware of any such blocking in the languages in our sample.

Finally, the standard may be introduced by a clause:

(35) Peter is taller than George is broad.

(36) Peter is taller than I had expected.

We follow Beck et al. (2012: 149) in calling this type the clausal comparative. In some languages, comparatives are negative polarity contexts. In our sample, there is no evidence for this pattern.

With comparatives, all possible relations may hold: $x \neq y, x=y, P=Q$ and $P \neq Q$.

\section{Superlative}

The score of a property attributed to the comparee differs from that of the same property attributed to the standard. The latter, being the comparison class, is necessarily a set with cardinality $\geq 2$ (cf. Gorshenin 2012: 59f.). The score attributed to the comparee is necessarily an endpoint relative to the values scored by the comparison class.

(37) John is the smartest (of all people in attendance).

(38) John is the least smart (of all/us). 
(39) John is the dumbest (of us all).

The score of the property attributed to the comparee may be a maximum (superlative of superiority/majority) or a minimum (superlative of inferiority/minority). As with comparatives, the latter is never expressed by a construction distinct from that of the former. Again, inferiority may be expressed lexically by use of a polar adjective, see (39). Superlatives are negative polarity contexts in some languages. The data in our samples are inconclusive as to this matter.

A special case worth mentioning is what Sapir (1944:113) calls the "unconditioned superlative" or "absolute superlative”, as in:

(40) John is the smartest man possible.

Here, the comparee is compared to every entity conceivable as a member of the standard.

With superlatives, necessarily $P=Q$. Further, the comparee is an element or a proper subset of the standard: $x \in Y$ or $X \subset Y$. The comparee $x$ is compared to every $y \in Y$.

Both in comparatives and superlatives, the standard may be omitted. As it can always be inferred from the context, we follow Beck et al. (2012: 148) in labeling this pattern contextual comparatives/superlatives.

\section{Elative}

The score of the property attributed to the comparee is different from the average in the comparison class. Typically, the deviation is to the upper end of the scale. However, the opposite is possible as well, as in Latin subacidus 'slightly acid' or German leidlich brauchbar 'moderately useful'. The deviation may be specified using various kinds of expression such as very, rather, quite or extremely, as in:

(41) John is very/rather/quite/extremely smart.

\section{Excessive}

The score of the property attributed to the comparee exceeds some contextually defined value.

(42) John is too smart.

In some languages, the excessive is a negative polarity context. The corpora investigated for this volume are inconclusive in this respect. 
The excessive is not the only construction which is used to rate the score of the property attributed to the comparee. Cf. (43), where the score of the property attributed to the comparee equals some contextually defined lower limit:

(43) John is smart enough.

\section{Relations between the notional types}

Some of the construction types discussed here can stand in for others. Thus, comparatives and superlatives can be used to denote elatives:

(44) He had a most pleasing personality.

(45) Input from the private sector and civil society is most welcome.

Also, in some of the languages presented here, comparatives may be used in superlative constructions. See 4.4 below and the individual chapters.

\section{Constructions expressing gradation}

For expository reasons, most examples in the following survey illustrate predicative constructions expressing gradation. We are aware of the fact that grading may also occur in attributive constructions and with other word classes like adverbs (see above):

(46) The smartest man wins the prize.

(47) John runs faster than George.

With rare exceptions, we do not use constructions like these as illustrations since attributive and adverbial constructions usually do not differ substantially from predicative constructions. Rather, for any given language the spectrum of attributive and adverbial constructions attested is always a proper subset of the attested predicative constructions. If differences occur, they are noted in the following chapters.

In the literature on comparison and gradation, terminology varies considerably; cf. the discussions in Cuzzolin (2011: 555) and Stolz (2013: 9). The labels of the constituents appearing in constructions expressing gradation used in this book are similar to those of Ultan (1972: 126).

We identify five primary constituents essential to any predicative comparative construction. In accordance with the ontology developed above and following Ultan we take four of these to be primitives (the abbreviations used in the following are given in parentheses):

(I) The comparee (CPREE), i.e. the entity which is set into a relation with or against some standard of comparison: 
(48) Peter is as tall as George.

(49) George is as tall as Peter.

Since (48) and (49) have the same truth conditions, selection of the comparee is due to topichood or profiling.

(II) The standard (STAND) against which the CPREE is compared. Standards do not necessarily have to be expressed, as they may be inferred from the context. Standards can also be introduced as scopes, i.e. as the set of entities from which the standard is taken. The difference can be seen from the following example:

(50) Peter is smarter than most of his friends in class.

While most of his friends is the standard to which Peter's smartness is compared, in class gives the set from which the standard is drawn. Scope may be expressed independently of standard:

(51) Peter is the smartest student in class.

(52) Peter is the smartest of all students.

As outlined above and evinced by (51) and (52), with superlatives the comparee is always a member of the reference set. In the glosses throughout this book, we only distinguish between proper standards and scopes in cases where both occur in one and the same example. Else, standard and scope are glossed uniformly by STAND.

Standards may either be introduced as phrases (phrasal comparison, e.g. ex. 50 above) or as clauses (clausal comparison):

(53) Peter is the smarter than anyone thought possible.

As discussed above, the standard is typically part of the discourse universe. With similatives, this is a necessary condition.

(III) The parameter (PAR), i.e. the property relative to which the CPREE is compared to the STAND. Due to their holistic nature, parameters are not obligatory (and never exclusive) with similatives,

(IV) The parameter marker (PM), which typically marks the value of the parameter attributed to the comparee relative to the standard. In cases where no degree is involved in the comparison, the parameter marker simply identifies the parameter. Parameter marker and parameter always form a constituent. The parameter marker does not necessarily have to be present as the parameter may be identified by its syntactic role and as the degree may be inferred from the context. 
The last label is not derived from the semantics of comparison, but it is an essential element of comparative constructions:

(V) The standard marker (STM) identifies the standard. It always forms a constituent with the latter. Absence of a standard necessarily implies absence of a standard marker. Standard markers may be specific to grading constructions, as with the dative of comparison in Old High German (see Jaeger \& Walkden, this volume). More frequently, they are non-specific. Many languages make use of simple noun phrase syntax (genitives), locative constructions, instrumental constructions, or separative constructions. Case may also be selected by adjectives of comparison like similar or verbs like to excel. As mentioned above, superlatives always pick an entity or subset from a reference set. Thus, STM with superlatives is never a designated marker introducing standards (or scopes), but rather a partitive case vel sim. Throughout this book, all standard markers, be they designated or not, are glossed as STM in the examples.

Optional additional constituents are multipliers (MULT) as in (54) and scores (SCORE) as in (55). Also, the difference on a scale (DIFF) may be made explicit, as in (56):

(54) Peter is twice as smart as George.

(55) Peter is by far the smartest guy around.

(56) Peter is taller than John by $20 \mathrm{~cm}$.

Various taxonomies of comparison constructions have been proposed in the literature. Cuzzolin (2011: 575f.) provides a brief overview of the classifications proposed by Stassen (1985), Heine (1997), Ultan (1972) and Cherberman (1999). To these may be added Hahnemann (1999), Dixon (2008, 2012), Gorshenin (2012) and Stolz (2013) as well as Haspelmath \& Buchholz (1998) and Haspelmath (2017) with regard to equative and similative constructions. The most recent review of the literature can be found in Treis (2018: iv-xviii).

In the present sketch we classify the constructions used to express comparison and gradation along two dimensions, STM and PM. Thus:

Table 1: Taxonomy of constructions

\begin{tabular}{lllll}
\hline PM & BM & FM & exceed/equate & - \\
STM & & & & \\
\hline flag & 1. flag / BM & 2. flag / FM & 3. flag / E & 4. flag / - \\
ptcl & 5. ptcl / BM & 6. ptcl / FM & 7.ptcl / E & 8. ptcl / - \\
- & 9. - / BM & 10. - / FM & 11. - / E & \\
\hline
\end{tabular}




\section{Abbreviations used: \\ $\mathrm{FM}=$ free morpheme. \\ $\mathrm{BM}=$ bound morpheme.}

We acknowledge that free morphemes and bound morphemes may be conceived of as end points of a cline; bound morphemes with word-like features (like the superlative marker -tama- in Avestan) should be noted.

$\mathrm{E}=$ exceed/equate-Type. Verbs, adjectives or adverbs with varying valency are attested as degree markers. If the comparee is an element of the standard, the exceed type necessarily has a superlative reading. If it is not an element of standard, a comparative reading results.

ptcl = the standard may be marked by a particle (which is either specific to grading constructions or has a broader scope, like Vedic yád). We use the term particle to denote any indeclinable sTM, be it morphologically complex (like Latin tamquam) or not (like Vedic ná).

flag = the standard is marked on the dependent by case or adposition (which, again, is either construction specific or has broader scope, like e.g. the genitive). We acknowledge the fact that case-marker and adposition are endpoints on a cline.

If attested, further subtypes will be listed without grouping them hierarchically. Note that all types are typically classified according to their semantics, not according to possible inferences. Thus, the semantics of a sentence like

\section{(57) John is not more clever than George.}

is that of a comparative (of inferiority). The fact that the negative polarity invites an inference as to the fact that John is either less clever or equal in cleverness to George (John $\leq$ George) is pragmatic and will be mostly ignored in the following survey. Data such as (57) are relevant only if such a construction were the sole, or at least the preferred, way of expressing inferiority (see e. g. Ittzés, this volume, on Latin).

In the following short overview, we present prototypical examples of the main patterns attested in the languages surveyed in this volume. We restrict ourselves to examples for structurally distinct constructions. Thus, except for the correlative diptych, comparisons with more than one parameter are not illustrated. Similarly for equatives and comparatives where CPREE and STAND are coreferential, and for superlatives and comparatives of inferiority/minority. For details, we refer to the contributions on individual languages. 


\subsection{Similative}

Similatives, being the most basic type of comparison, are attested in all ancient IE languages except for those attested in exceedingly small and/or fragmented corpora.

The most basic pattern of similatives corresponds to type 4 or 8 of our taxonomy, since no parameter is involved:

(58) Vedic (RV 3.36.8)

$\begin{array}{llll}\text { hradà } & \text { iva } & \text { kukșáyaḥ } & \text { somadhấnāḥ } \\ \text { lake.NOM.PL } & \text { like } & \text { cheek.NOM.PL } & \text { holding-Soma.NOM.PL } \\ \text { STAND- } & \text { STM } & \text { CPREE } & \text {-STAND }\end{array}$

'His cheeks are like lakes of Soma.'

This pattern is common throughout the languages documented in this volume, either with a particle or a flag as STM. In Hittite, an affix deriving denominal adverbs is attested as STM. See Molina, this volume. Frequently, a parameter profiled in the otherwise holistic comparison is given explicitly. The most common pattern is seen in (59), where the STM is a particle:

(59) Ancient Greek (Homer, Iliad 14.185)

$\begin{array}{lllll}\text { leukòn } & d \text { ' } & \tilde{\tilde{e}} & \text { éélios } & \text { hốs } \\ \text { white.NOM } & \text { but } & \text { be.IPF.3SG } & \text { sun.NOM } & \text { like } \\ \text { PAR } & & \text { [CPREE] } & \text { STAND } & \text { STM } \\ \text { 'white } & & & \end{array}$

'white was it like the sun'

In the languages documented in this volume, designated case markers for standards in similatives are not attested. (But see Milizia, this volume, on Ossetic.) Frequently, the parameter marker (PM) is expressed by a verb or an adjective. The standard is then flagged by a case selected by the governing verb or adjective:

(60) Vedic (RV 1.52.11; Zeilfelder 2001: 128)

$\begin{array}{llllll}\text { te... } & \text { sáho } & \text { dyấm } & \text { ánu } & \text { śávasā } & \text { barhánāa } \\ \text { 2sG.DAT } & \text { might.NOM } & \text { heaven.ACC } & \text { towards } & \text { majesty.INS } & \text { power.INS } \\ & \text { CPREE } & \text { STAND.STM } & \text { PM- } & \text { PAR } & \text { PAR }\end{array}$

bhuvat

be.INJ.3SG

$-\mathrm{PM}$

'your might ... was equal to heaven in majesty and power'

Compounding, not covered by our taxonomy, is another pattern frequently attested for expressing similatives (or equatives): 
(61) Ancient Greek (Homer, Hesiod, passim)

rhodo-dáktylos

rose-finger

STAND CPREE

'having fingers like roses'

\subsection{Equative}

As mentioned above, similatives and equatives are hardly distinguishable in non-informant languages. Various types are attested. The most frequent ones are those where the STM is a particle. They occur either with or without a PM, as seen in (62) and (63) respectively:

(62) Latin (Cic. de orat. 1.251)

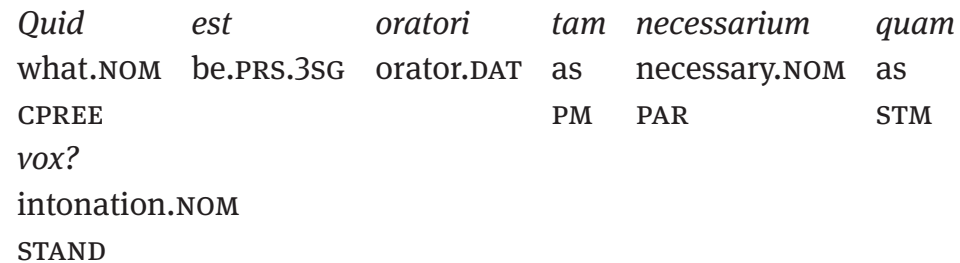

'What is so essential to an orator as intonation?'

(63) Vedic (RV 1.8.5; Zeilfelder 2001: 129)

dyaúr ná prathiná śávah

heaven.NOM like width.INS power.NOM

STAND STM PAR CPREE

'wide as the heaven extends his power'

In Breton, PAR and PM can be repeated for comparee and standard:

(64) (Early) Modern Breton (HMSB: 50)

$\begin{array}{lllllllll}\text { an } & \text { tri } & \text { ferson=ze } & \text { zo } & \text { ker } & \text { koz } & \text { ha } & \text { ker } & \text { koz } \\ \text { ART } & 3 & \text { person-DEM } & \text { is } & \text { EQD } & \text { old } & \text { and } & \text { EQD } & \text { old } \\ & & \text { CPREE.STAND } & & \text { PM } & \text { PAR } & & \text { PM } & \text { PAR }\end{array}$

'those three persons are equally old'

As with similatives, verbs or adjectives are also frequent PMs. The following Greek example (65) illustrates the pattern. The relevant verb is notably construed with two datives; thus Pérsēisi may be licensed either by plêtheï or by the infinitive mákhesthai, its second instantiation being elided under identity. 
(65) Ancient Greek (Herodotus 7.103.4)

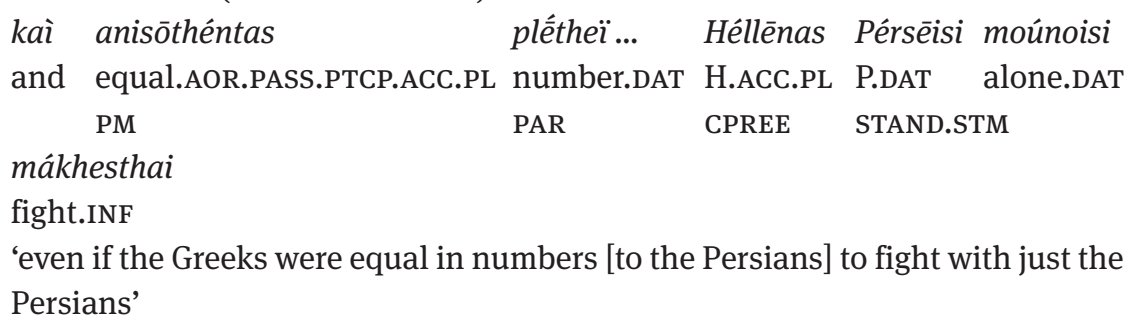

Only in the Insular Celtic languages is the parameter marked by a bound morpheme, the equative degree (EQD). Cf. (66), with an adposition as the STM:

(66) Middle Irish (Corm. 36)

$\begin{array}{lllll}\text { comdhub } & \text { fri } & \text { héc } & a & \text { drech } \\ \text { EQD.dark } & \text { to } & \text { death } & \text { his } & \text { face } \\ \text { PM.PAR } & \text { STM } & \text { STAND } & & \text { CPREE }\end{array}$

'his face is as dark as death'

On the correlative diptych, which is also widely attested in ancient IE languages, see

(25) above; on comparatives in equative constructions, see (26) above.

Equatives can be used as exclamatives. This pattern is attested e.g. in Classical Armenian. It is grammaticalized in Middle Breton (see Nurmio \& Russell, this volume).

\subsection{Comparative}

In most ancient IE languages with the notable exception of Anatolian and the Tocharian languages, the parameter is marked by a degree marker, be it an affix or an unbound morpheme. In all the languages in our corpus which make use of bound PMs, constructions with free ones are also attested; cf. the following Latin examples:

(67) Latin (Cic. Catil. 1.11)

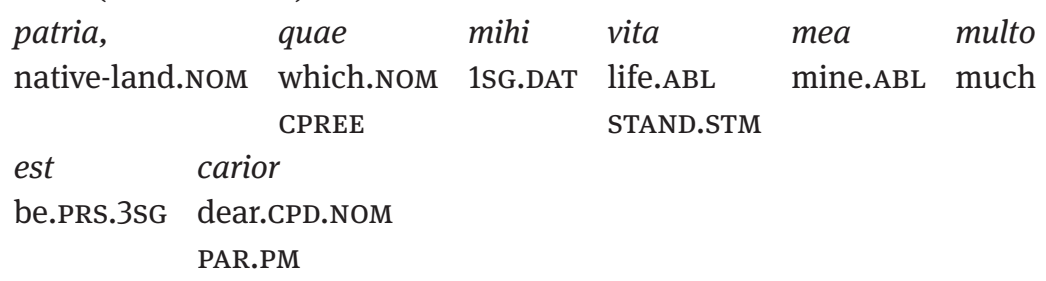

'my native land, which is much more dear than my life' 
(68) Latin (Verg. Aen. 5.724f.)

$\begin{array}{lllll}\text { Nate, } & \text { mihi } & \text { vita ... } & \text { care } & \text { magis } \\ \text { born.voc } & \text { 1SG.DAT } & \text { life.ABL } & \text { dear.voc } & \text { more } \\ \text { CPREE } & & \text { STAND.STM } & \text { PAR } & \text { PM }\end{array}$

'my son, more dear than life'

The data suggest that in languages where both types are attested, the distribution is essentially free, though there seem to be preferences for one or the other type in some languages (see e.g. Ittzés, this volume, on Latin). In Tocharian as in Anatolian, ungraded adjectives are used throughout in comparative constructions, as PMS marking degree do not exist:

(69) Tocharian B (THT 496a2)

$\begin{array}{lllll}\text { (wno)lme ... } & m \bar{a} & \text { cisa } & \text { lāre } & \text { mäsketär=ñ } \\ \text { being.NOM ... } & \text { not } & \text { 2sg.PERL } & \text { dear.NOM } & \text { be.PRS.3SG-1SG } \\ \text { CPREE } & & \text { STAND.STM } & \text { PAR } & \end{array}$

'there is no one dearer to me than you'

Ungraded adjectives in comparative constructions are also attested in Epic Sanskrit (see Kulikov, this volume).

Two basic ways of introducing the standard are attested in our corpus, either by case or adposition or by use of a comparative particle. The cases or adpositions used as STMS else typically denote spacial relations, be it separation or location, as in:

(70) Ancient Greek (Homer, Iliad 1.186; Cuzzolin 2014: 332)

$\begin{array}{llll}\text { hósson } & \text { phérterós } & \text { eimi } & \text { séthen } \\ \text { how much } & \text { strong.CPD.NOM } & \text { be.PRS.1SG } & \text { 2SG.from } \\ & \text { PAR.PM } & \text { [CPREE] } & \text { STAND.STM }\end{array}$

'how much stronger I am than you'

While case marking of STMS is typically restricted to just one case (with rare exceptions e. g. in Latin or Old Lithuanian), this does not hold for adpositions, as e. g. Greek and Latin attest a variety of different tokens in this function. There is no evidence for allatives as STMs in ancient IE languages. Cross-linguistically, this is hardly surprising since "the goal schema is relatively uncommon globally" (Stolz 2013: 80), whereas separatives and locatives are frequent throughout the world. Notably, even in languages with rich case systems, adpositions are also used in this function - an exception being Old Indo-Aryan.

Non-local cases are rare as STMS: The Germanic languages mark the standard by dative case (see Jäger \& Walkden, this volume): 
(71) Gothic (1 Cor. 10.22)

$\begin{array}{llll}\text { ibai } & \text { swinpozans } & \text { imma } & \text { sium? } \\ \text { Q } & \text { strong.CPD.NOM } & \text { he.DAT } & \text { be.PRS.1PL } \\ & \text { PAR.PM } & \text { STAND.STM } & \text { [CPREE] }\end{array}$

'are we stronger than he?'

In other languages, different non-local cases may be attested, though they are never prototypical for comparative constructions. See (72) for an instrumental in this function:

(72) Old Lithuanian (Jonas Bretkūnas, Biblia 1580: VII. 141r ${ }_{21 \text { f., }}$ Luke 12.24; Fraenkel 1928: 181)

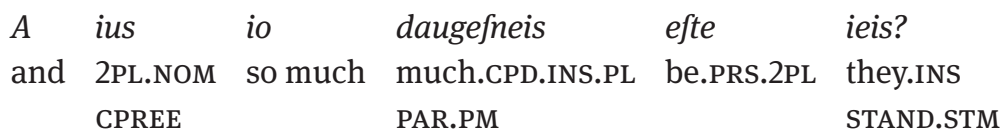

'Of how much more value are you than they!'

The instrumental is also attested as STM in Epic Sanskrit (see Kulikov, this volume).

Particles are equally frequent as STMS as cases and adpositions in our corpus. Often, as in the following example from Vedic, they stand in free distribution with case or adpositions.

(73) Vedic (AB 3,29,6; Delbrück 1888: 196)

$\begin{array}{lllll}\text { ūrdhvāh } & \text { purușasya } & \text { bhūyāmsah } & \text { prāṇa } & \text { yac } \\ \text { upper.NOM.PL } & \text { man.GEN } & \text { numerous.CPD.NOM.PL } & \text { organ.NOM.PL } & \text { than } \\ \text { CPREE } & & \text { PAR.PM } & & \text { CPREE } \\ \text { cāvāñcah } & & & \\ \text { and.lower.NOM.PL } & & & \\ \text { STAND } & & \end{array}$

'the upper organs of the human body are more numerous than the lower ones'

Here, the particle used is the most general Vedic subordinator, yád. Most other languages in our corpus make use of particles with a much more restricted scope. This is the case of Armenian, one of the languages in our corpus which only use particles as STMS:

(74) Classical Armenian (Matt. 3.11; Zeilfelder 1996: 179)

\begin{tabular}{|c|c|c|c|c|c|c|}
\hline or & zknin & im & gay & hzawragoyn & $k^{\prime} a n$ & zis \\
\hline REL.NOM & after & 1SG.GEN & come.PRS.3SG & mighty.CPD.NOM & than & ACC.1SG \\
\hline CPREE & & & & PAR.PM & STM & STAND \\
\hline
\end{tabular}

'he who is coming after me is mightier than I' 
Verbs or adjectives can be used as PMs in most of the languages in our corpus, though this construction is nowhere prototypical. An example from Latin is (75):

(75) Latin (Tac., dial. 26.6)

$\begin{array}{llll}\begin{array}{l}\text { ipsarum } \\ \text { itself.GEN.PL }\end{array} & \begin{array}{l}\text { virium } \\ \text { strength.GEN.PL }\end{array} & \begin{array}{l}\text { robore } \\ \text { solidity.ABL } \\ \text { PAR }\end{array} & \begin{array}{l}\text { multum } \\ \text { superat }\end{array} \\ \text { PM.[CPREE] } & \begin{array}{l}\text { ceteros } \\ \text { the other.ACC.PL } \\ \text { STAND.STM }\end{array} \\ \text { surpass.PRS.3SG } \\ \text { 'he is far superior to all in the solidity of his very strength' }\end{array}$

In all ancient IE languages, standards are not obligatory if they can be inferred from the context. Constructions omitting the standard, however, always presuppose constructions with standards.

\subsection{Superlative}

The existence of designated superlative constructions presupposes that of comparatives. The standard with superlatives is always properly speaking its scope (see above regarding exx. 51 and 52), i. e. a set with cardinality $\geq 2$ of which the CPREE is a member. Thus, it is always quantificational. With designated superlatives particles as standard markers are not attested in the languages in our sample. Like in the case of comparatives, STMs with superlatives may be bound or unbound morphemes, as seen below in (76) and (77) respectively. The distribution is identical to that attested with comparatives.

(76) Latin (Cic., fam. 7.17)

\begin{tabular}{cllll}
..., quod & a & te & alienissimum est, \\
what.NOM & from & 2SG.ABL alien.SPD.NOM be.PRS.3SG \\
CPREE & STM & STAND PAR.PM & videbare \\
subimpudens & \multicolumn{4}{c}{ vide }
\end{tabular}

somewhat-shameless.NOM seem.IPF.PASs.2SG

'what is most alien to you, [namely] that you seemed somewhat shameless' 
(77) Latin (Plaut., Capt. 1.1)

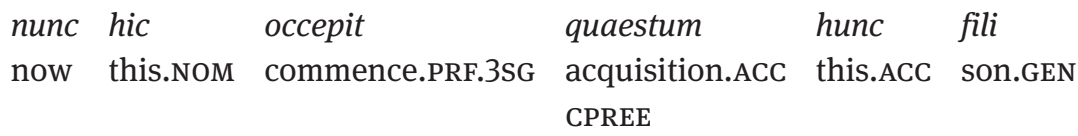

$\begin{array}{llllll}\text { gratia inhonestum } & \text { et } & \text { maxime } & \text { alienum } & \text { ingenio } \\ \text { for } & \text { dishonorable.ACC } & \text { and } & \text { most } & \text { alien.ACC } & \text { inclination.DAT } \\ & & & \text { PM } & \text { PAR } & \text { STAND.STM }\end{array}$

suo

OWn.DAT

'Now, for the sake of his son, has he commenced this dishonorable traffic, most alien to his own inclination.'

In languages like post-Homeric Greek, where determiners are obligatory, the parameter is always definite (see de Kreij, this volume). Remarkably, even in languages with PMs explicitly marking superlatives, morphological comparatives are frequent in superlative constructions. The superlative reading is a logical consequence of negated existential quantification, as in (78):

(78) Vedic (RV 2.33.10; Zeilfelder 2001: 156)

$\begin{array}{llllll}n a ́ & v a \bar{a} & \text { ójīyo } & \text { rudra } & \text { tvád } & \text { asti } \\ \text { NEG } & \text { and } & \text { mighty.CPD.NOM } & \text { R.vOC } & \text { 2SG.ABL } & \text { be.PRS.3SG } \\ & & \text { PAR.PM+CPREE } & & \text { STAND.STM } & \end{array}$

'there is not a mightier than you, Rudra'

However, in some languages, comparative morphology may be used in superlative readings outside negated contexts if the standard contains a universal quantifier:

(79) Old Lithuanian (Konstantynas Sirvydas, Punktay sakimu I.177 ) $^{2}$

Chriftus ... ira ftebuklingiefnis terp wifu

Chr.NOM be.PRS. wonderful.CPD.NOM among all.GEN.PL

$\begin{array}{lll}\text { CPREE } & \text { PAR.PM STM STAND }\end{array}$

futwerimu

creature.GEN.PL

'Christ is the most wonderful among all creatures.'

Similar patterns are attested in Classical Armenian (see Kölligan, this volume). In Middle Irish, the formal comparative has ousted the superlative completely (see Griffith, this volume).

As with comparatives, superlatives are not formally marked by a PM in Anatolian and in the Tocharian languages: 
(80) Hittite (KBo III 7 IV 15-17)

$\begin{array}{llll}\text { DINGIR.MEŠ=naš } & \text { hūmandaš } & { }^{d} \text { Zašhapunaš } & \text { šalliš } \\ \text { god.DAT.PL } & \text { all.DAT.PL } & \text { Z.NOM } & \text { great.NOM } \\ \text { STAND.STM } & & \text { CPREE } & \text { PAR }\end{array}$

'Zašhapunaš ist the greatest of all gods'

Note that the cross-linguistically frequent type of ungraded adjective plus focal element is not attested in our sample.

In accordance with the semantics outlined above, the STM with superlatives, be it a case or an adposition, prototypically denotes partitivity. This is true of the Ancient Greek genitive in (81) and of the Old Lithuanian adposition in (82):

(81) Ancient Greek (Homer, Iliad 2.673f.; Ziemer 1884: 55, Zeilfelder 2001: 364)

$\begin{array}{llllll}\text { Nireús, } & \text { hòs } & \text { kállistos } & \text { anèr ... } & \text { tôn } & \text { állōn } \\ \text { N.NOM } & \text { REL.NOM } & \text { comely.SPD.NOM } & \text { man.NOM } & \text { ART.GEN.PL } & \text { other.GEN.PL } \\ \text { CPREE } & & \text { PAR.PM } & & \text { STAND.STM } & \end{array}$

Danaȭn

D.GEN.PL

'Nireus the comeliest man ... of all the Danaans'

(82) Old Lithuanian (Mikalojus Daukša, Postilla Catholicka 1599: 181 ${ }_{12}$ )

$\begin{array}{lllll}\text { Pékta } & \text { żime } & \text { didj̇éufia } & v \dot{z} & \text { wiffäs. } \\ \text { fifth.NOM } & \text { sign.NOM } & \text { big.SPD.NOM } & \text { for } & \text { all.ACC.PL } \\ \text { CPREE } & & \text { PAR.PM } & \text { STM } & \text { STAND }\end{array}$

'The fifth sign is the biggest of all.'

Verbs or adjectives may be used as PMs, but as with comparatives such constructions are never the default pattern. The type is attested e.g. in Ancient Greek:

(83) Ancient Greek (Homer, Iliad 23.742f.)

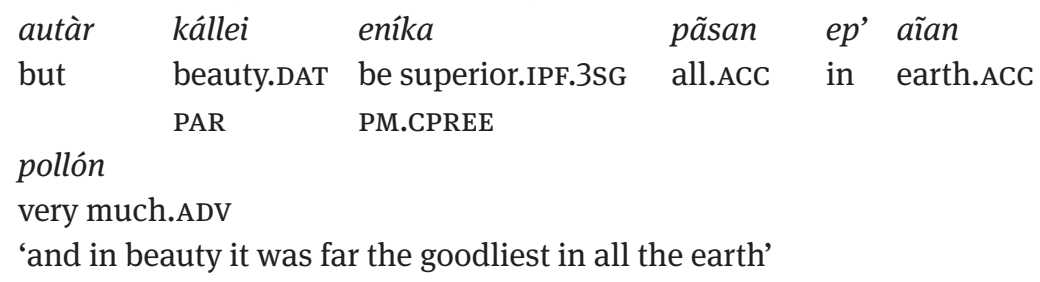

As with the comparative, the standard may be omitted if reconstructible from the context. This type presupposes the existence of related constructions with expressed standard. 


\subsection{Elative}

Elatives, which due to their semantics outlined above are never attested with a standard, come in two flavors. They may be based on morphological superlatives or comparatives, as seen in (84) and (85) respectively:

(84) Latin (Enn. ann. 599; Cuzzolin 2011: 641)

equitatus iit celerissimus

cavalry.NOM go.PRF.3SG fast.SPD.NOM

CPREE

PAR.PM

'the cavalry went on very fast'

(85) Ancient Greek (Herodotus 3.53.1)

allá hoi katephaíneto eĩnai nōthésteros

but he.DAT seem.IPF.3SG be.INF stupid.CPD.NOM

[CPREE] PAR.PM

'(his eldest son,) who seemed to him to be slow-witted' [ 'rather stupid']

The other, widely attested type is morphological, either with prefixation as in (86) or, much more rarely, with reduplication as in (87):

(86) Ancient Greek (Appianus Historicus, BC 4.4.29)

épaulin héteros eĩkhe perikallẽ

country house.ACC other.NOM have.IPF.3SG very handsome.ACC

[CPREE] [PM].PAR

'another man had a very handsome country-place'

(87) Epic Sanskrit (DKCar 2,5,24,1; Speyer 1886: 191)

kșāmakșāmāpi devatānubhāvād anatikșinnavarṇāvakāśā

quite emaciated=even divinity.dignity.ABL unweakened-colour.place.NOM

PAR.[PM]

CPREE

sìmantinī

woman.NOM

CPREE

'a woman, who though [of a] rather thin [aspect] had by divine power not too much lost of the brightness of her colour'

Finally, elative semantics can be expressed by a huge variety of intensifiers such as adverbs or parts of compounds as e.g. in German hundemüde or totmüde, both 'very tired' (see 5.2.1 below). An example from Greek is (88): 
(88) Ancient Greek (Homer, Iliad 16.46; Schwab 1895: 167)

$\begin{array}{lllll}\text { hòs pháto } & \text { lissómenos } & \text { méga } & \text { népios } \\ \text { so } & \text { speek.AOR.MID.3SG } & \text { praying.NOM } & \text { very } & \text { silly.NOM } \\ & \text { [CPREE] } & & \text { PM } & \text { PAR }\end{array}$

'so spake he in prayer, fool that he was' [ 'very silly']

Note that méga is otherwise not attested in grading constructions.

\subsection{Excessive}

Like the elative, the excessive is never attested with a standard. Most frequently, it is based on a morphological comparative.

(89) Latin (Cato agr. 61.1; Cuzzolin 2011: 593)

$\begin{array}{lllll}\text { si male arabit, } & \text { radices } & \text { susum } & \text { abibunt, } \\ \text { if badly plow.FUT.3SG } & \begin{array}{l}\text { root.NOM.PL up } \\ \text { CPREE }\end{array} & & \text { go forth.FUT.3PL }\end{array}$

crassiores fient

thick.CPD.NOM.PL become.FUT.3PL

PAR.PM

'while bad plowing will cause the roots to come to the surface and grow too large'

The free morphemes attested as PMs in excessive constructions are typically not related to parameter markers used in other types of gradation. Cf. Ancient Greek:

(90) Ancient Greek (Aristophanes, Ach. 471 f.)

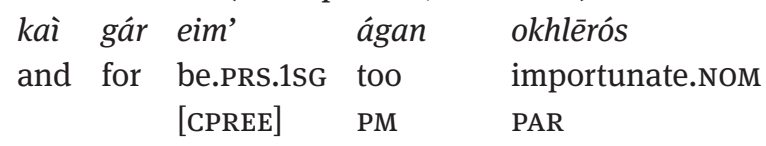

'I am too importunate'

Rarely, the parameter can be marked by a verb. This type is also attested in Ancient Greek: 
(91) Ancient Greek (Euripides, Ba. 785)
ou gàr all' huperbállei tâ
NEG for but exceed.PRS.3SG that.ACC if from woman.GEN.PL PM.[CPREE]
peisómesth' hà páskhomen
suffer.FUT.1PL REL.ACC suffer.PRS.1PL
'for it is indeed too much if we suffer what we are suffering at the hands of women'

This concludes our survey of the basic constructions attested to express comparison or grading in the languages presented in this volume. For details we refer to the individual chapters.

\section{Formal means of expressing grading and comparison}

In this section, morphology is used in a broader sense comprising not only proper word formation processes like prefixing, suffixing, compounding etc., but also modifications of basic concepts by adverbs and grading particles as well as suppletive forms or terms consisting of several words. While the basic terms (Sapir's 'quantifiables') are in principle not linked to a specific part of speech, the overtly graded form as used in comparative constructions is in general an adjective or an adverb. But there are cases of graded nouns as well, e.g. Vedic sómapāh somapấvnām 'the best soma-drinker' (RV 1.30.11) or Old Norse mør meyja 'the most beautiful girl' (Jensen 1934: 112). Grading and intensification are hard to distinguish from each other semantically, although not every intensive form can be used in comparative constructions, e.g. German/ English tot/dead - mausetot/stone-dead, but *töter/deader (Thurmair 2001: 104 fn. 2).

The classification follows the traditional morphological (resp. morphosyntactical) construction types and includes any word form or complex phrase which expresses a higher or lower degree of the corresponding basic notion, provided the graded form can be used in one (or more than one) of the above constructions. 


\subsection{Affixes}

\subsubsection{Suffixes}

Most Indo-European languages continue in one form or another the competing reconstructed suffixes ${ }^{*}$-yes-/-yos- (comparative) / ${ }^{*}$-is-to- (superlative) and ${ }^{*}$ - $($ t)ero- (comparative) $/{ }^{*}-(t H)-m o$ - (superlative) - the latter suffixes, however, were not restricted to gradation. Some languages developed new suffixes, e. g. Lithuanian. -iaus- (superlative). These suffixes occur typically with adjectival bases, but are not restricted to them. Comparative and superlative forms can be made from nouns, e.g. Vedic vīrátara-/vīrátama- 'more/most hero-like' (vīrá- 'hero'), Ancient Greek kúnteros/kúntatos 'more/most dog-like, shameless' (kúōn 'dog'), from adverbs, e.g. Vedic ádhara-/ adhamá- 'lower/lowest' (ádha 'below'), Ancient Greek ã sson/ágkhistos 'nearer/ nearest' (ágkhi 'near') or verbal bases, e. g. Vedic yájìyas-/yájișțha- 'better/best sacrificer' (yaj- 'offer, sacrifice'). In any case, the outcome of this process always seems to be an adjective, i.e. these suffixes have a double function of marking degree and word class (Zeilfelder 2001: 28-40). But in Sanskrit there are instances of comparatives to the third person singular of the present, e.g. sìdatetarām 'is more despondent', vyathayatitarām 'disturbs more' (Whitney ${ }^{2} 1889$ : 176, Speyer 1886: 189); corresponding superlatives are taught by Pāninini (5,3,56): pacatitamām 'cooks exceedingly well, cooks best of all' and jalpatitamām 'chatters very much, chatters more than all' (Speyer 1886: 189; -tarām/-tamām <-tara-/-tama- +-ām). Many of these formations do not constitute a whole paradigm; sometimes there is no synchronic base at all, e.g. Ancient Greek ameínōn 'better' (cf. 4.3 Suppletion). Ancient Greek -tero- and Avestan -tama-/ Vedic -tama- trigger morphonological processes which suggest that similar to parts of compounds these suffixes had word-like status (Wackernagel 1889). Zeilfelder gives a comprehensive overview of the suffixal comparative and superlative formations in Vedic (2001: 224-291) and Homeric Greek (2001: 355-359). It is not unusual to accumulate more than one degree marker, e.g. Sanskrit papiyastara- 'worse' from the comparative papiyas- with the same meaning. Suffixes with equative (similative) function are attested in Insular Celtic, e.g. Old Irish dénithir 'as swift' (dian 'swift'), fírithir 'as true' (fir 'true').

\subsubsection{Prefixes}

Prefixes are widely used for the elative type, e.g. Latin perbonus 'very good', supergloriosus 'exceedingly glorious', subacidus 'somewhat sour, sourish', Ancient Greek perikallếs 'very beautiful', hupérkalos 'exceedingly beautiful', Old Church Slavonic prěmodrъ 'very wise'. But prefixes can be found as well in comparative and superlative constructions, cf. Old Church Slavonic nailučbšii 'the best', naivęšte adv. 'most'. 


\subsubsection{Reduplication}

To our knowledge partial reduplication is not attested as a grading device in ancient IE languages. Full reduplication, however, does occur. See (88) above as well as Classical Armenian mecamec 'very big', jermajerm 'very warm', or Sanskrit dịnadinna- 'very wretched or miserable' (Speyer 1886: 191). Note that in other languages, such as Malagasy, reduplication weakens the meaning of the adjective (Haspelmath \& Sims ${ }^{22010:}$ 38).

\subsection{Constructions involving several lexemes}

\subsubsection{Compounds}

Compounds occur in similatives and equatives (see above ex. 61 and the ample documentation in the individual chapters) as well as in elatives, e. g. German fuchsteufelswild 'mad as hell' (van Os 1989), Vedic vấtajūta- 'as swift as the wind', Sanskrit paramamahat- 'infinitely great', Ancient Greek arípikros 'very bitter', agaklutós 'very famous'.

\subsubsection{Lexical degree marker}

The higher or lower degree of a property can be expressed analytically by using an adverb or a grading particle. A whole range of intensifiers with adjectives, nouns, and verbs in English is presented in Bolinger's 1972 study Degree Words. Klein (1998: 20-23) proposes a classification of degree adverbs in Dutch, German, and English ranging from I 'absolute degree' (completely, absolutely) to VIII 'negative degree' (not, not a bit) including the intermediate stages II 'approximative' (almost, nearly), III 'extremely high' (extremely, awfully), IV 'high' (very), V 'moderate' (rather, pretty), VI 'minimal' (somewhat, a bit) and VII 'quasinegative' (little, hardly). Such adverbs occur in older stages of Indo-European languages as well, e. g. Latin satis litteratus 'of considerable literary culture', mire gratus 'greatly welcomed' or valde longus 'very long', Ancient Greek teléōs áphrōn ‘completely insane’, órthios iskhurỗs 'exceedingly steep’ or epieikỗs stenós 'rather narrow' (Schwab 1895: 165-199). Whereas degree adverbs of this kind are mostly used in the elative type, the analytic comparative and superlative is usually characterized by adverbs like 'more/most' or 'less/least', e. g. Latin magis mirum 'more marvelous' (Cuzzolin 2011: 576). In the languages discussed in this book analytic forms are the only means to express comparatives and superlatives of minority, see e. g. Latin minus sapiens 'less wise'. Other lexical means are used for example in Russian (e.g. samyj čistyj 'the cleanest'), in Latvian (e.g. pats labais 'the best'), and in Rumanian (e.g. cam incert 'rather uncertain', with cam < quam). Double marking 
is frequent in Late Latin, e.g. magis fortior 'much stronger' (Hofmann \& Szantyr 1965: $166 \mathrm{f}$.) and also occurs in Ancient Greek, e.g. rhēiteroi mãllon (Homer, Iliad 24.243) 'much easier', ékhthistos ... málist' 'hateful above all' (Homer, Iliad 2.220; Schwab 1895: 70, Zeilfelder 2001: 363).

\subsubsection{Complex phrases}

In some languages complex phrases are used to express a certain degree. Constructions with figura etymologica to convey the highest degree are widespread: Ancient Greek agathós pãsan aretến 'good with regard to goodness' = 'very good', ánax anáktōn 'the lord of the lords' = 'the greatest lord' (Schwab 1895: 198f.), Modern Armenian vater-i vat-a 'the bad of the bad' = 'the worst' (Jensen 1934: $111 \mathrm{f}$.). In most cases, however, this stylistic device is used to intensify, often connected with already marked comparative or superlative forms: RV 9.97.3 yaśástaro yaśásām lit. 'the more honored among the honored', RV 2.33.3 tavástamas tavásām 'the strongest of the strong', Sanskrit priyātpriyatara- 'dearer than dear' = 'the very dearest' (Speyer 1886: 190). 'Quasielative' (Reiter 1979: 134) expressions like Modern Greek krýos mpoúzi 'ice-cold’ or Sursilvan in buontad vin 'an excellent wine' (lit. 'in goodness wine') (Lausberg 1972: 94) are not attested in our corpus.

\subsection{Suppletion}

Gaps in paradigms of comparative and superlative forms are sometimes filled ('supplied') by morphologically unrelated forms both in grammars and in actual language usage (cf. Schwyzer \& Debrunner 1950: 184). Nearly all Indo-European languages use suppletion in comparison to a certain extent, cf. classical patterns like Latin bonus melior - optimus or Ancient Greek agathós - beltioon - béltistos 'good - better - best'. Suppletion of the comparative necessarily implies that the superlative is suppletive, too. Either it is based on the stem of the comparative (like in the Greek example), or it has a suppletive stem of its own (as in the Latin example). Dieu (2009) provides a good survey of suppletion in comparison in Indo-European languages with special emphasis on Ancient Greek.

\subsection{The syntax of gradation and comparison}

Word order in grading constructions follows the general pattern attested in each language. We refer to the individual sections for details and illustrations. Attributive and predicative constructions differ with respect to word order in Classical Armenian 
(see Kölligan, this volume). In Old and Middle Irish, graded adjectives are blocked in attributive use (see Griffith, this volume). ${ }^{8}$

Some types of grading constructions are (possible) negative polarity contexts. This is evident for comparatives in the West Germanic languages and Old Lithuanian (the latter probably under German influence). With both comparatives and superlatives Latin makes use of different PMs depending on the polarity (see Ittzés, this volume). The connection of grading and negative polarity is also evident from the fact that in Greek, Vedic, and Baltic, the standard marker is or can be based on a negation. See the respective chapters for details.

Constructions omitting the standard do not differ structurally from those with an explicit standard in our corpus. Rather, they are built on the latter.

\section{The questionnaire}

It is a central aim of this book to present a detailed and exhaustive picture of comparison and gradation for each of the early Indo-European languages or subphyla covered and to ensure cross-linguistic comparability. In accordance with the topdown approach developed here, we thus presented the contributors with a questionnaire covering if not all, then at least the most pertinent constructions expressing the various types of comparison. The questionnaire is based on the general types of comparison distinguished in section 2 and the taxonomy of constructions given in section 3, table 1. Consequently, each of the following chapters is - at least in principle - structured identically.

Each chapter comprises sections on the similative, the equative, the comparative, the superlative, the elative, and the excessive, in that order. Each of these sections presents the constructions attested in identical fashion across type and across languages or subphyla. Thus, in each of the following chapters all the attested constructions for each type of comparison are discussed and illustrated in the order of the construction types given in table 2 .

8 The Attributive Comparative Generalization of Pancheva (2009) and Lechner (2017), which states that attributive comparatives in languages like German must be c-commanded by the comparee, cannot be corroborated by the data in our corpus. (It may be noted in passing that in our view the observed patterns are actually due to an adjacency condition.) 
Table 2: Construction types

\begin{tabular}{|c|c|c|c|c|c|c|}
\hline $\begin{array}{l}\text { Constructions } \\
\text { Types } \\
\text { (STM / PM) }\end{array}$ & $\begin{array}{l}\text { 1. Simila- } \\
\text { tive }\end{array}$ & 2. Equative & $\begin{array}{l}\text { 3. Compara- } \\
\text { tive }\end{array}$ & $\begin{array}{l}\text { 4. Superla- } \\
\text { tive }\end{array}$ & 5. Elative & 6. Excessive \\
\hline Type 1 (flag / BM): & $1-1$ & $2-1$ & $3-1$ & 4-1 & & \\
\hline flag is case & 1-1-1 & $2-1-1$ & $3-1-1$ & 4-1-1 & & \\
\hline flag is adpos. & $1-1-2$ & $2-1-2$ & $3-1-2$ & $4-1-2$ & & \\
\hline Type 2 (flag / FM): & $1-2$ & $2-2$ & $3-2$ & $4-2$ & & \\
\hline flag is case & $1-2-1$ & $2-2-1$ & $3-2-1$ & $4-2-1$ & & \\
\hline flag is adpos. & $1-2-2$ & $2-2-2$ & $3-2-2$ & $4-2-2$ & & \\
\hline Type 3 (flag / E): & $1-3$ & $2-3$ & $3-3$ & $4-3$ & & \\
\hline flag is case & $1-3-1$ & $2-3-1$ & $3-3-1$ & 4-3-1 & & \\
\hline flag is adpos. & $1-3-2$ & $2-3-2$ & $3-3-2$ & $4-3-2$ & & \\
\hline Type 4 (flag / - ): & $1-4$ & $2-4$ & $3-4$ & $4-4$ & & \\
\hline flag is case & $1-4-1$ & $2-4-1$ & $3-4-1$ & 4-4-1 & & \\
\hline flag is adpos. & $1-4-2$ & $2-4-2$ & $3-4-2$ & $4-4-2$ & & \\
\hline Type 5 (ptcl / BM) & $1-5$ & $2-5$ & $3-5$ & 4-5 & & \\
\hline Type 6 (ptcl / FM) & $1-6$ & $2-6$ & $3-6$ & $4-6$ & & \\
\hline Type 7 (ptcl / E) & $1-7$ & $2-7$ & $3-7$ & 4-7 & & \\
\hline Type 8 (ptcl / -) & $1-8$ & $2-8$ & $3-8$ & 4-8 & & \\
\hline Type 9 (- / BM) & $1-9$ & $2-9$ & $3-9$ & 4-9 & $5-9$ & $6-9$ \\
\hline Type 10 (- / FM) & $1-10$ & $2-10$ & $3-10$ & $4-10$ & $5-10$ & $6-10$ \\
\hline Type 11 (- / E) & $1-11$ & $2-11$ & 3-11 & 4-11 & $5-11$ & $6-11$ \\
\hline
\end{tabular}

For each type of comparison, constructions not covered by this taxonomy are given in an additional subsection if necessary. The sections close with surveys of the formal means of expressing the type of comparison under discussion.

Additional data further illustrating the patterns discussed in the chapters of this book are available at https://gitlab.uzh.ch/paul.widmer/mhiet-vol1-gradation.

\section{References}

Beck, Sigrid (2011). “Comparative Constructions”. In: Semantics: An International Handbook of Natural Language Meaning. Bd. 2. Ed. by C. Maienborn, K. von Heusinger \& P. Portner. Berlin: De Gruyter Mouton, 1341-1389.

Beck, Sigrid, Toshiko Oda \& Koji Sugisaki (2004). "Parametric variation in the semantics of comparison: Japanese versus English”. In: Journal of East-Asian Linguistics 13, 289-344.

Beck, Sigrid, Daniel Fleischer, Remus Gergel, Stefan Hofstetter, Sveta Krasikova, Christiane Savelsberg, John Vandereist \& Elisabeth Villalta (2009). "Cross-linguistic variation in comparison constructions". In: Linguistic Variation Yearbook 8, 1-66.

Beck, Sigrid, Vera Hohaus \& Sonja Tiemann (2012). “A Note on Phrasal Comparatives”. In: Proceedings of SALT 22, 146-165.

Bolinger, Dwight (1972). Degree words. Berlin: De Gruyter. 
Bresnan, Joan (1973). "Syntax of the Comparative Clause in English". In: Linguistic Inquiry 4, 275-343.

Cherberman, Klemens-Peter (= Herbermann, Clemens-Peter) (1999). "Komparativnye konstrukcii v sravnenii: K voprosu ob otnošenii grammatiki k ètimologii i jazykovoj tipologii”. In: Voprosy jazykoznanija 2, 92-107.

Cuzzolin, Pierluigi (2011). “Comparative and superlative”. In: New perspectives on historical Latin syntax. Ed. by Philip Baldi \& Pierluigi Cuzzolin. Berlin, Boston: de Gruyter, 549-659.

Cuzzolin, Pierluigi (2014). “Comparison”. In: Encyclopedia of Ancient Greek language and linguistics. Ed. by Georgios K. Giannakis. Leiden, Boston: Brill, 331-334.

Delbrück, Berthold (1888). Altindische Syntax. Halle a. S.: Verl. der Buchhandlung des Waisenhauses.

Dieu, Éric. (2011). Le supplétisme dans les formes de gradation en grec ancien et dans les langues indo-européennes. Genève: Droz.

Dixon, R. M. W. (2008). “Comparative constructions: A cross-linguistic typology”. In: Studies in Language 32, 787-817.

Dixon, R. M. W. (2012). “Comparative constructions”. In: Dixon, R. M. W.: Basic Linguistic Theory. Volume 3. Further Grammatical Topics. Oxford, New York: Oxford University Press, 343-375.

Fraenkel, Ernst (1928). Syntax der litauischen Kasus. Kaunas: Valstybės Spaustuvė.

Gorshenin, Maksym (2012). “The crosslinguistics of the superlative”. In: Neues aus der Bremer Linguistikwerkstatt. Aktuelle Themen und Projekte. Ed. by Cornelia Stroh. Bochum: Brockmeyer, 55-160.

Hahnemann, Suzan (1999). Vergleiche im Vergleich. Zur Syntax und Semantik ausgewählter Vergleichsstrukturen mit 'als' und 'wie' im Deutschen. Tübingen: Niemeyer.

Haspelmath, Martin (2017). "Equative constructions in world-wide perspective”. In: Similative and Equative Constructions. A cross-linguistic perspective. Ed. by Yvonne Treis \& Martine Vanhove. Amsterdam, Philadelphia: Benjamins, 9-32.

Haspelmath, Martin \& Oda Buchholz (1998). "Equative and similative constructions in the languages of Europe". In: Adverbial constructions in the languages of Europe. Ed. by Johan van der Auwera. Berlin: Mouton de Gruyter, 277-334.

Haspelmath, Martin \& Andrea D. Sims (2010). Understanding morphology. $2^{\text {nd }}$ edition. London: Hodder Education.

Heine, Bernd (1997). The Cognitive Foundations of Grammar. New York: Oxford University Press. Hofmann, Johann Baptist \& Anton Szantyr (1965). Lateinische Syntax und Stilistik. München: Beck.

Ittzés, Máté (fthc.). “Melle dulcior: equative or comparative?” In: Linguisticae Dissertationes. Current Perspectives on Latin Grammar, Lexicon and Pragmatics. Selected Papers from the $20^{\text {th }}$ International Colloquium on Latin (Las Palmas de Gran Canaria, Spain, June 17-21, 2019). Ed. by Antonio Maria Martín Rodríguez. Madrid: Ediciones Clásicas.

Jäger, Agnes (2018). Vergleichskonstruktionen im Deutschen: Diachroner Wandel und synchrone Variation. Berlin: de Gruyter.

Jenny, Mathias (2017). "Comparative, similative, and equative constructions in Mon”. In: Similative and Equative Constructions. A cross-linguistic perspective. Ed. by Yvonne Treis \& Martine Vanhove. Amsterdam, Philadelphia: Benjamins, 291-319.

Jensen, Hans (1934). “Der steigernde Vergleich und sein sprachlicher Ausdruck”. In: Indogermanische Forschungen 52, 108-130.

Kennedy, Christopher (2001). "Polar Opposition and the Ontology of 'Degrees”.' In: Linguistics and Philosophy 24, 33-70.

Klein, Henny (1998). Adverbs of degree in Dutch and related languages. Amsterdam, Philadelphia: Benjamins. 
Kühner, Raphael \& Carl Stegmann (1997 [= 21914]). Ausführliche Grammatik der lateinischen Sprache. Teil 2. Satzlehre. Bd. 2. Unveränd., reprograf. Nachdr. d. 2., neubearb. Aufl., Hannover 1914, mit den Zusätzen und Berichtigungen zur 3. Aufl. 1955 sowie den Berichtigungen zur 4. Aufl. 1962 und zur 5. Aufl. 1976 von Andreas Thierfelder. Darmstadt: Wissenschaftliche Buchgesellschaft.

Langacker, Ronald W. (1987). Foundations of Cognitive Grammar. Vol.1. Theoretical Prerequisites. Stanford: Stanford University Press.

Lausberg, Heinrich (1972). Romanische Sprachwissenschaft. III. Formenlehre. 2. durchges. Aufl. Berlin, New York: Walter de Gruyter.

Lechner, Winfried (2017). "Phrasal comparatives and Parasitic Scope”. In: Wiener Linguistische Gazette 82, 181-191.

Os, Charles van (1989). Aspekte der Intensivierung im Deutschen. Tübingen: Narr.

Pancheva, Roumyana (2009). "More Students Attended FASL than CONSOLE”. In: Formal Approaches to Slavic Linguistics 18: The Cornell Meeting, 2009. Ed. by W. Browne, A. Cooper, A. Fisher, E. Kesici, N. Predolac \& D. Zec. Ann Arbor: Michigan Slavic Publishers, 383-400.

Reiter, Norbert (1979). Komparative. Wiesbaden: Harrassowitz.

Sapir, Edward (1944). “On grading: A study in semantics”. In: Philosophy of Sciences 11, 93-116. Repr. in: Mandelbaum, David G. (ed.) (1949). Selected Writings of Edward Sapir in Language, Culture and Personality. Berkeley and Los Angeles: University of California Press, 122-149.

Schwab, Otto (1893-1895). Historische Syntax der griechischen Comparation in der klassischen Literatur. I.-III. Heft. Würzburg: Stuber.

Schwyzer, Eduard \& Albert Debrunner (1950). Griechische Grammatik. Bd. 2. Syntax und syntaktische Stilistik. München: Beck.

Seuren, Pieter A. (1973). “The Comparative”. In: Generative Grammar in Europe. Ed. by F. Kiefer \& N. Ruwet. Dordrecht: Riedel, 528-564.

Small, George W. (1924). The comparison of inequality. The semantics and syntax of the comparative particle in English. Baltimore: John Hopkins University.

Speyer, Jacob S. (1896). Sanskrit Syntax. Leyden: Brill.

Stassen, Leon (1985). Comparison and Universal Grammar. Oxford: Blackwell.

Stechow, Arnim von (1984). "Comparing Semantic Theories of Comparison”. In: Journal of Semantics 3, 1-77.

Stolz, Thomas (2013). Competing Comparative Constructions in Europe. Berlin: Akademie Verlag.

Tarriño, Eusebia (2011). “Comparative clauses”. In: New perspectives on historical Latin syntax. Ed. by Philip Baldi \& Pierluigi Cuzzolin. Berlin, Boston: de Gruyter, 373-426.

Thurmair, Maria (2001). Vergleiche und Vergleichen. Eine Studie zu Form und Funktion der Vergleichsstrukturen im Deutschen. Tübingen: Niemeyer.

Treis, Yvonne (2018). “Comparative Constructions: An introduction”. In: Linguistic Discovery 16.1, i-xxvi.

Treis, Yvonne \& Martine Vanhove (eds.) (2017). Similative and Equative Constructions. A cross-linguistic perspective. Amsterdam, Philadelphia: Benjamins.

Ultan, Russell (1972). "Some features of basic comparative constructions". In: Working papers on Language Universals 9, 117-162.

Vanhove, Martine (2017). "Similative, equative, and comparative constructions in Beja (North-Cushitic)". In: Similative and Equative Constructions. A cross-linguistic perspective. Ed. by Yvonne Treis \& Martine Vanhove. Amsterdam, Philadelphia: Benjamins, 189-211.

Wackernagel, Jacob (1889). Das Dehnungsgesetz der griechischen Komposita. Programm zur Rektoratsfeier der Universität Basel. Basel.

Whitney, William Dwight (1889). A Sanskrit grammar, including both the classical language, and the older dialects, of Veda and Brahmana. 2. rev. and extended ed. Leipzig: Breitkopf \& Härtel. 
Zeilfelder, Susanne (1996). "Syntax des Komparativs im Altarmenischen”. In: Historische Sprachforschung 109, 175-198.

Zeilfelder, Susanne (2001). Steigern und Vergleichen in indogermanischen Sprachen. Habilitationsschrift Universität Jena.

Ziemer, Hermann (1884). Vergleichende Syntax der indogermanischen Comparation, insbesondere der Comparationscasus der indogermanischen Sprachen und sein Ersatz. Berlin: Dümmler. 
